IN THE Red CROSS WORLD

\title{
A GLIMPSE AT THE RED CROSS IN LATIN AMERICA
}

Mr. José Gómez Ruiz, Deputy Director of the Junior Red Cross Bureau of the League, went some time ago to South America. There, he attended two meetings organized under the auspices of the League of Red Cross Societies and visited several National Societies whose various activities he was able to observe; as he describes in the article which he has kindly written for the International Review.

The distance separating Geneva from Latin America is so great that information on the activities of the National Red Cross Societies in that part of the world is not infrequently incomplete. Anyone therefore who has the privilege of visiting these Societies is better able to realize what magnificent work they accomplish daily. The Red Cross in Latin America enjoys the respect and esteem of the population.

A National Society may transport to the military hospital a civilian patient whose state of health calls for treatment which can only be given in that hospital. This privilege has been granted to the Red Cross in recognition of the services given by its voluntary workers and it is a further testimony to the prestige of our institution.

Yet a further example may be given. The leaders of the Junior Red Cross, belonging to University circles, are called upon to give courses on the Geneva Conventions in the civil service schools for police officers. They are also responsible, in co-operation with the Red Cross nurses, for giving instruction to teachers in rural areas to enable them to qualify for the diploma of monitor of the Junior Red Cross. In addition, as the dynamic vigour and surety for the future of the Red Cross, they prepare television programmes of first aid instruction. 
The spirit of dedication displayed by these Societies appeared to me to be most striking during two regional meetings recently held in Peru-attended by National Societies from the North, and in Chile-attended by National Societies from the Southern part of the continent. The delegates resolved that one of the National Societies should undertake to co-ordinate the activities of other Red Cross Societies in a particular field (e.g. first-aid, Junior Red Cross, relief work, blood transfusion, etc.) and to submit a report to the next Inter-American Conference of the Red Cross which will be held in Bogota in November 1966. ${ }^{1}$

This is something original : the National Societies have voluntarily agreed to accept instructions from a sister Society in a neighbouring country, in order the better to develop activity in a particular field. Is this not proof of a degree of maturity and agreement of which the Societies concerned might well be proud? It also illustrates the general desire to improve efficiency, to consolidate each day their position as auxiliaries to the public authorities and to be able the better to alleviate suffering everywhere and without discrimination. It is not to be wondered at that the first Red Cross Society on the American continent was founded in Peru in 1879.

The meetings at Lima in Peru and at Santiago de Chile were to my mind vivid demonstrations of the will to serve with which these National Societies are infused. The frank and forthright manner in which they described their work, their achievements and their failures, is the best proof that the Red Cross in Latin America is led by people who are conscious of their responsibilities and desire constantly to perfect their knowledge in order the better to accomplish the tasks incumbent on them.

To conclude this brief exposition, I would like to mention an incident which recently occurred in one of the South American countries. Following the decision of the Government to break off diplomatic relations with one of the other countries, the student bodies organized a protest meeting which soon degenerated into a riot. The police tried to disperse the crowd, of which a large section sought refuge in the University where it was "besieged". The

${ }^{1}$ It will be recalled that the Lima and Santiago meetings were held pursuant to a recommendation by the VIIth Inter-American Conference of the Red Cross at Puerto Rico; see International Review. January 1963. 
rumour spread that there were some casualties in this group and the population asked the Red Cross to intervene. After obtaining the agreement of the Government authorities, the leaders of the Red Cross were able to go into the University and then to give the authorities and the public an objective report on the true situation. They were also permitted by the Government to supply blankets to the people inside the University buildings.

One of the main aims of a Red Cross Society is, in my opinion, to win the full confidence both of the Government and of the people in its country. As can be seen from this incident, the National Society had succeeded in achieving this objective, and the events to which I have alluded show that the Red Cross in Latin America is a force to be reckoned with.

José Gómez Ruíz 